\title{
Immunity in Context: Science and Society in Dialogue
}

\begin{abstract}
Alfred I. TAuber
Received: $29 / 05 / 2015$

Final Version: $28 / 10 / 2015$

BIBLID 0495-4548(2016)31:2p.207-224

DOI: $10.1387 /$ theoria. 14560

ABSTRACT: According to immunology's prevailing paradigm, immunity is based on self/nonself discrimination and thus requires a construction of identity. Two orientations vie for dominance: The original conception, conceived in the context of infectious diseases, regards the organism as insular and autonomous, an entity that requires defense of its borders. An alternate view places the organism firmly in its environment in which both benign and onerous encounters occur. On this latter relational account, active tolerance allows for cooperative relationships with other organisms in the larger ecological economy. These contending orientations - one derived from biomedicine and the other from the ecological sciences- have drawn the attention of social scientists and culture critics. On the one hand, feminists have portrayed immune theory as based upon borrowed social notions of identity that reflect male aggressive values and thus distort more balanced accounts of immunity; and, on the other hand, other commentary projects immune theory as a framework in which analysis of Western societies putatively reveals analogous patterns of 'self and 'other' interactions, where autoimmunity and immunization are understood as expressions of the insular understanding of identity. Here, a meta-interpretation is presented that shows how these critiques place the immune self on a spectrum stretching from its formulation as an autonomous agent, a modernist conception of the independent individual, to a postmodern portrayal in which this conception of selfhood has been deconstructed. Accordingly, immunology is drawn into a wide-ranging debate about agency, where differing interpretations of immunity serves as a template in which competing understandings of human social intercourse is modeled.
\end{abstract}

Key words: immunology, immunity, selfhood, postmodernism, ecology, individuality.

RESUMEN: Según el paradigma dominante en inmunología, la inmunidad está basada en la discriminación entre yo/noyo y requiere, por tanto, una construcción de la identidad. Dos orientaciones compiten por dominar: la concepción original, concebida en el contexto de las enfermedades infecciosas contempla al organismo como aislado y autónomo, como una entidad que necesita defender sus fronteras. Una visión alternativa sitúa firmemente al organismo en su entorno, en el cual suceden tanto encuentros beneficiosos como costosos. En este enfoque relacional, la tolerancia activa permite relaciones cooperativas con otros organismos en una economía ecológica más amplia. Estas orientaciones en liza —una derivada de la biomedicina y otra de las ciencias ecológicas - han llamado la atención de los científicos sociales y de los críticos de la cultura. Por una parte, el feminismo ha descrito la teoría inmunológica como basada en nociones sociales prestadas de identidad que reflejan los valores agresivos del macho y que, de este modo, impiden una explicación más equilibrada de la inmunidad. Por otra parte, otro comentario proyecta la teoría inmunológica como un marco en el que el análisis de las sociedades occidentales revela aparentemente patrones análogos de interacciones 'yo' y 'otros', en las que la autoinmunidad y la inmunización son entendidas como expresiones de la comprensión insular de la identidad. Se ofrece aquí una meta-representación que muestra cómo estas críticas sitúan al yo inmune en un espectro que va desde su formulación como un agente autónomo, una concepción modernista del individuo independiente, a una visión postmoderna en la que esta concepción de la identidad ha sido deconstruida. De acuerdo con esto, la inmunología recoge un amplio debate sobre la agencia en el que diferentes interpretaciones de la inmunidad sirven como molde en el que se modelan comprensiones competidoras de la comprensión de las relaciones sociales humanas.

Palabras clave: Inmunología, inmunidad, identidad, postmodernismo, ecología, individualidad. 


\section{Introduction}

Contemporary immunology has established its fundamental theory as a biological expression of personal identity, wherein the immune self is defended by the immune system. We can trace this theme to those discoveries that led to the discovery of the bacterial etiology of infectious diseases and the elucidation of host defense mechanisms that soon followed (Silverstein 2009). This is the historical account of a clinical science, a tool of medicine, and as such it focuses almost exclusively on the role of immunity as a defender of the host. And, of course, the host of greatest interest is the patient, a "self" suffering from microbial attack.

Critical appraisal of immunology's dominant paradigm reveals a major presupposition, namely, that there is a definable self that might be defended. This view has been subject to rigorous scientific debate (Langman 2000). Indeed, because autoimmunity and tolerance are increasingly regarded as falling on a broad spectrum of immune responses and self/nonself differentiation cannot be reduced to molecular signatures, stable boundaries of the immune self have evaded definition (Matzinger 1994; Tauber 2000; Pradeu 2010; 2012). According to these views, immunity is not in service to an entity, a self, but rather immune activities have assumed an anthropomorphic agency because of ideas projected from common notions of personal identity.

This formulation of immune identity has been challenged by a medley of findings that have highlighted how the kind of immune response evoked is framed by the context in which the object is encountered rather than its intrinsic foreign character relative to some stable entity. In other words, the self/nonself model is not governed by simple on/off rules, because discrimination that determines identity plays on a dynamic spectrum of functional criteria (Tauber 2015a; 2015b). And with that alteration in immunology's principal model, immune identity assumes various degrees of "liquidity" (Grignolio et al., 2014). On the revisionist account, aging, differing nutrition, and altered geography continuously reshape the antigenicity of physical entities and thus create new targets of oral tolerance or rejection. Correspondingly, identity changes over time. Simply stated, immune profiles are highly contingent on individual experience and cannot remain static (Brodin et al., 2015). From this understanding the status of the immune self as a governing principle of immunology falters.

The hitherto dominant defensive orientation largely ignores the role of active immune tolerance that mediates the organism's intercourse with its environment and, more generally, the co-operative relationships characterizing the holobiont and symbionts with which the organism co-exists (Gilbert, Sapp and Tauber 2012). ${ }^{1}$ A newly recognized 'ecological imperative' is gaining influence, in which entities "are what they are because of the environment in which they are found" (Birch and Cobb 1981, 94). Eco-immunology has emerged as a field of study that integrates immunology and ecology, and with that synthesis, the notion of an organism in dynamic relationships accounts for both predator relationships as

1 As summarized by Margulis (1991), 'symbiosis' has several meanings and refers to at least four kinds of relationships: 1) spatial (obligate and facultative), 2) temporal (cyclical, permanent, behavioral) 3) metabolic (partial/total dependence, biotrophic, metabolic), and 4) genetic (gene-product transfer [protein, RNA] or gene transfer). The assembly of different organisms into co-operative complex consortia, designates a holobiont (Rosenberg et al., 2007), which defies any singular definition of organismal identity as independent agents. 
well as the complex economies of organisms in collective associations and in benevolent intercourse with their environment (Gewin 2011; Martin, Hawley and Ardia 2011; Demas and Nelson 2011; Maligoli and Ottaviani 2014). This new inter-disciplinary field thus widens the scope of immunity and thereby shifts the focus of immune functions to a larger framework that allows for both competitive and co-operative exchanges. In that move, the line demarcating self and other wavers. Add the normal surveillance functions of the "resting" immune system engaged in the ordinary physiology of cell turnover and other internal "housekeeping" immunity assumes integration with normal physiology (Tauber 2015a). Accordingly, the immune system regulates the identity of organism - both within and without - to encompass traditional defensive functions as well as tolerant ones. On this view, a more fully ecological understanding of immunity declares a revision that balances defense and cooperation (Ulvestad 2007; Tauber 2008a; 2008b; Swiatczak 2013).

When older definitions of immunity shift from the original defensive formulation in service to an autonomous entity to one that embraces an ecological orientation, agency assumes a relational structure and new designs of identity are invoked. That scientific shift has been described elsewhere (Tauber 2013a; 2015a; 2015b), and here I examine the toand-fro exchange of immunology's key idiom, the immune self, as it moves between the laboratory and its wider social culture. That dialogue reflects the scientific debate concerning the nature of immunity, which in turn determines how immune identity is characterized. At this focus point swirling around selfhood, the laboratory and its supporting culture meet. That conceptual re-orientation has resonance beyond the laboratory and constitutes a rich example of science and society in dialogue.

\section{Immunology in dialogue}

Given that immunology has been defined as the science of self/nonself discrimination, the centrality of agency pervades immune theory and practice. Indeed, the immune self has rich metaphorical appeal and has enjoyed great idiomatic utility in modeling immune functions (Crist and Tauber 1999). Critics have argued that immunology, a science of cells and molecules, has been widely coopted to naturalize folk psychology about what it means to be a self. And more, they have detected deep resonances between the utility of immune selfhood and broader characterizations of personal identity that structure Western societies. So on these interpretations, on the one hand, immunology inculcates social values into the descriptions and interpretations of immunological phenomena, and, on the other hand, immunity is a ready vehicle for characterizing the society in which 'selves' live. This is science traveling on a two-way highway.

A vast science studies literature has discussed how science draws from a broad spectrum of extra-curricular influences, which stretch from the almost trivial mapping of the social scientific practice (Latour and Woolgar 1979; Mody and Kaiser 2008) to the very core of scientific conceptualizing. Regarding immunology specifically, these sources may be considered from several perspectives:

1. Immunologists have borrowed from philosophical and psychological notions of personal identity to fashion various formulations of immune selfhood (Tauber 1994), whose limits have been extensively discussed within the scientific commu- 
nity (Langman 2000). Immunology's uses of self and its congeners have been easily extracted from cultural resources and philosophical formulations to inform various models of immunity and have thus served as ready models for assigning identity functions (Tauber 1994). The most ubiquitous meaning refers to a construction of identity (the immune self) that is characterized by an insular autonomy and employs circumscribed borders to distinguish itself from others (Löwy 1991; Howes 2010).

2. The socio-political elements of immunology have been easily tracked to the discipline's grounding in the clinical setting and the complex sociology of laboratory organization and funding (e.g. Löwy 1992; 1996; Keating and Cambrosio 2003), which in turn is largely determined by the medical challenges set before immunologists (Silverstein 2009).

3. Institutional support frames immunology's investigative agenda. These influences range from the dictates delivered by government through financial commitments and policy decrees; positive responses to wider industrial (Croissant and SmithDoerr 2008), military (Rappert, Balmer and Stone 2008), and political (Rouse 1987; Greenberg 2007) interests; and acknowledgement of citizen activism for disease-specific research (Bucchi and Neresini 2008; Hess et al., 2008).

4. Feminists argue that immunologists are oriented by a male ethos in which domination and aggressive competitive modalities have organized the discipline in ways inimical to seeing cooperative relationships and inclusive tolerance as the mainstays of immunity (e.g. Weasel 2001; Napier 2003; 2012; Howes 2008, 2012; ScheperHughes 2012). Few would dispute the general adage that scientists both actively draw from, and are directed by, their supporting culture, but feminist commentators have contended that the immune self as a scientific concept refracts cultural mores, submerged prejudices, and undeclared political agendas. (This is a more radical position than the modest "pluralistic" [Wilson 2005, 11-14] claim described above by \#1).

5. How cognitive and linguistic faculties influence thinking among immunologists has not been examined, but such an analysis seems warranted. The putative direction (even restrictions) embedded in cognitive grammar (Langacker 2008) and linguistic relativism (known as the Whorf hypothesis) - weak and strong forms, notwithstanding - argues that language frames human reality, a thesis that has generated much comment and tentative affirmative conclusions (e.g., Lakoff 1987; Gumperz and Levinson 1996; Boroditsky 2009).

No matter where one falls on the wide spectrum of these constructivist and political interpretations does not mitigate the general epistemological conclusion: Immunology, like all sciences, cannot be segregated from the extra-curricular support derived from diverse influences (reviewed in Tauber 2009), or as Donna Haraway quips, "the messy political does not go away because we think we are cleanly in the zone of the technical" (Haraway 1997, 68).

In this regard, critics from the social sciences have taken note of immunology's conceptual underpinnings and have offered a diverse array of interpretations of immune theory. This trade in ideas reflects constructivist commitments, where science is seen as drawing from social, philosophical, and linguistic sources to model natural phenomena and, in turn, 
scientific constructions offer metaphors and tropes for culture critics to assess society. In short, how the immune self is conceptually configured is not solely the provenance of laboratory scientists. Indeed, the self crosses disciplinary borders with ease.

The most charged flash point concerns the biological agent viewed from the perspective of a host compromised - either subject to infection, aggressive malignancy, or transplantation. Immunology's central premise is that such an individual must have its compromised identity restored by effective immunity. The language of cognition widely used to describe immune functions (e.g., 'recognition,' 'memory,' 'learning,') supports this general identification with the human subject (Tauber 1997; 2013a). Indeed, the 'cognitive metaphor' draws from a core knowing entity closely akin to a Cartesian understanding of a thinking thing (Tauber 1994). ${ }^{2}$ And the general acceptance that humans are 'selves' finds resonant support in the way immunity builds upon implicit Western understanding of individuality, a value highly prized (and protected) in First World democracies. However, the notion of an autonomous, individuality characterizing immune selfhood drew barbed comment from those who regarded such a construction as imported from particular notions of social identity. Support for a more relational understanding of immunity echoes social theory emphasizing the co-operative character of social intercourse.

Commentators have assigned cultural values to the insular immune conception by noting that the evident social differences between races, men and women, workers and managers, or citizens and foreigners have surreptitiously been imported into immune theory. While some would regard such distinctions characteristic of modern notions of identity, culture critics have highlighted that there is nothing 'natural' about such differences. (Haraway 1989a, Martin 1990; 1994; Rossiianov 2008). Instead they regard the self/nonself basis of immune discrimination as a projection of social prejudice, namely, a way of making contested social boundaries a "natural" characteristic of social collectives. So just as Social Darwinians promoted "the survival of the fittest" as a trope to capture the social essence of America a century ago, today "immune reaction" putatively functions in parallel fashion to that earlier projection (Napier 2003). ${ }^{3}$ The warfare metaphors — "attack," "defense," "invaders" - so prevalent in immunology's lexicon, dramatically illustrate this construction, both in terms of the self/nonself dichotomy, as well as the privileged standing of

2 "The cognitive metaphor is operative whenever psychological terms are used to describe actions or behaviors of nonpsychological agents [viz. nervous and immune systems/functions], or to explain actions or behaviors not caused by psychological states.... When microbiologists conceptualize organisms as recognizing the presence of a pathogen, or a virus as choosing hosts with diminished immune systems, they invoke the cognitive metaphor...and it is manifest in talk of cell migration, neural memories, molecular signaling, preferential developmental pathways, the goal of maximizing gene replication, and of biochemical systems as seeking equilibria. The cognitive metaphor is ubiquitous in the life sciences" (Wilson 2005, 75).

3 With the exploration of this idea comes David Napier's social criticism - highlighted difference and protected personal boundaries rule at the expense of true tolerance, social integration, and free communication. For Napier, the basic schema of an 'I' who must be defended against 'them' is more than just metaphorical: This scientific conceptualization has been internalized into our collective social psyche. Napier sees the dominant immunological precepts as little different from simple demonology made respectable by its appeal to science. The so-called "Age of Immunology" may thus be regarded as the power of a scientific paradigm about self and non-self that confirms and contributes to "our culture at war with itself" (Napier 2003, 7). 
individuality over the commune. This interpretation and others akin to it thus regard immune models based on host defense as instantiating an ideological orientation of social barriers, as opposed to constructions based on co-operation and collective action (Haraway 1989a). Accordingly, immunology provides a political metaphor for American culture marked by atomistic individuality, and more provocatively, this cultural bias has putatively seeped into immune theory by valorizing an individuality celebrating personalized self-fulfillment at the expense of communal values.

However, as already described, an ecologically inspired research program challenges immunity conceived solely in a defensive format, and it has enjoyed a generous reception among some of immunology's sociological critics. In support of this alternate relational formulation of immune agency, they have argued that the foreign is not necessarily threatening or dangerous (Haraway 1989a; Weasel 2001). ${ }^{4}$ This is most clearly appreciated when the immune self is portrayed in its full ecological context. Accordingly, instead of a modernist notion of the self as a given entity neatly defined, i.e., entailed by its own "selfness" and guarded by an immune system, an 'ecological' understanding of organismic identity reconfigures the agent in dialectical encounter with the world, both within the body of the animal and beyond the host in a world fraught by ambiguous friend and foe relationships (Levins and Lewontin 1985). This view is not a vague metaphysical interpretation, but rather a conception based on immune activity determined by the mutually affecting presence of the other and a revised understanding of autoimmunity and the ecological placement of the organism.

\section{The immune self co-opted}

Whether or not immunologists have explicitly appropriated cultural notions of personal identity for their models of immunity, the idea of 'immunity' has strong public appeal and has percolated into common notions of biological selfhood. The AIDS epidemic serves as a particular vivid example of that authority, where HIV is popularly conceived as literally destroying 'the self (Martin 1994). And social critics have taken immunity - centered on extrapolated notions of 'immunization' and 'autoimmunity' - to characterize capitalist societies. Some would even maintain "immunological ideas now provide the primary conceptual framework in which human relations take place in the contemporary world" (Napier 2003, $3)$. In the more recent chapters of this interchange, socio-political critics, who argue that "the self" serves as a metaphor to model contemporary Western societies, have further extended a confrontational understanding of immune function by invoking "immunization" as an explanatory model for understanding their core dynamics. For example, Roberto Esposito (2011) (who cites Niklas Luhmann, Ulrich Beck, Zygmunt Bauman [ibid., 193],

4 While feminist critics abhor the power relations of supremacy of 'self over 'other' that projects certain masculine ideals of dominance, the focus of their critique centers on a deeper epistemological stratum, namely that the self/other distinction is based on a masculine cognitive form of objectivity derived from such domination (Keller 1982; Harding 1986; 1991). Note, this line of argument includes the suggestion that women themselves, because of their feminine socialization, possess an epistemological perspective, which differentiates them from their male colleagues (Keller 1983; 1985; 1992; Haraway 1989b; Weasel 2001, 36-9). 
and Jacques Derrida [ibid., 53] in support of this interpretation) maintains that immunization captures the danger of contamination by the (social) 'other' (immigrant, lower classes, etc.) and the corresponding need to protect the social integrity of the invaded group. So, in these writings, the self, appearing under the guise of immunization, returns to the socio-political lexicon to model social theory, namely by asserting that immunization characterizes large-scale human intercourse, for better and for worse.

Note, concomitant with the newly achieved social fluidity of a global economy and cyber-world connections, these critics see a counter-balance required for attaining some defensive equilibrium between self and other reminiscent of the older uses of the immune self in immunology (Swiatczak 2013). The metaphor's wide application - from religion and metaphysics to housing and cities - invokes the dialectics of borders and exchange, individuality and communes. Thus immunization is regarded as both protective and, in some sense, "lethal," inasmuch as the foreign must be introduced as part of the immunization itself. In other words, just as in the immune system, the balance of intrusion and defense characterizes the social "bubble" in which humans live (Sloterdijk 2011).

Autoimmunity has also been co-opted by social critics (reviewed by Anderson and Mackay 2014, 144-54). Most notably, Jacques Derrida regarded autoimmunity as the instantiation of the selfs own deconstruction, by which he meant that an internal process compromised the integrity of the person, i.e., sovereign integrity, but in that destruction, opportunities for transformation arose (Derrida 1994, 2003). In other words, autoimmunity, while destructive was also a liberating or positive force providing for self-renewal. ${ }^{5}$

If we broaden the scope in which the contested definition or meaning of selfhood includes critiques from anthropology, philosophy, psychology, and feminism (e.g., Taylor 1989; Butler 1993; Morris 1994; Foucault 2005), an extraordinary expanse of ideas still require placement into the general question of how implicit notions of personal identity have found expression in immune theory and vice versa. So while it is too early to judge the extent immune concepts have influenced cultural conceptions of the individual in the social sciences and self-identification in Western cultures more broadly, clearly a larger role is emerging. And, conversely, beyond using immunity to characterize the social, and placing a social perspective upon immune theory, some social scientists are looking at immunology to guide them in their own re-appraisal of assumptions concerning how 'selfhood' functions in anthropology (Napier 2012a, 2012b; Scheper-Hughes 2012; Stollar 2012), inasmuch as the immune construction seemingly so clearly illustrates the ambivalent and reciprocal status of the Same and the Other (Moulin 2001; Moulin and Cambrosio 2001).

A final note concerning the relevance of this discussion: Although social critics have argued that immune theory borrows from the cultural conceptions of identity, the scientist characteristically takes little notice of such claims. Such correspondences and their deeper philosophical significance are not of her concern in a first order way, namely, in determining what she investigates or how. At the level of the laboratory then, little compels the investigator to heed these commentators, who might easily be dismissed as simply projecting their own biases, while the immunologist is focused on discovering facts. That facts must be interpreted (an exercise in which the play of values and subtle extra-curricular elements

5 In regards to the 'betrayal of the body,' see also Esposito $(2011,17,18,141,159)$ and Mark Taylor (1993). 
are inescapable) generally is unappreciated (Tauber 2009). And precisely at this point, interpretation, the critic places her interest. We need not adjudicate the exchange, however, it seems self-evident that the dialogue described here has most significance for those concerned with understanding cultural currents and their philosophical underpinnings. And to the extent contemporary formulations of immunity contribute to that analysis, we must decide what constitutes judicious comment and what may be dismissed as only provocative speculation. In the following discussion, an array of conjectures is entertained.

\section{The specter of postmodernism}

When this critical sociological literature is placed in its larger intellectual framework, postmodern themes clearly appear. If the organism is conceived as an autonomous individual, a modernist understanding emerges, attendant with ideas about autonomy and protective borders, an agent owning social autonomy and exercising self-knowledge. And when regarded with a different conception of selfhood, one formed in line with certain current philosophical critiques of mind and postmodern portrayals of selfhood, then very different characteristics will be appreciated. ${ }^{6}$ On these "deconstructed" philosophical and sociological accounts, the self has been decentered, disenfranchised, and left untethered from its modernist conceits (e.g., Deleuze and Guattari 1977; Cadava, Connor and Nancy 1991; Foucault 2005). Indeed, on this view, capturing 'the self has become an abdicated philosophical project (Tauber 2013b). ${ }^{7}$

Given the pervasive influence of these re-conceptions of personal identity, immune selfhood has been re-considered along the same postmodern lines (Tauber 1995; Weasel 2001; Code 2006), a view that has kindred support in ecology (e.g., Drengson and Inoue

6 This general orientation also has growing influence in contemporary philosophies of mind, where the self as such does not exist, but rather a phenomenal self - a process, not an entity - appears in conscious experience. (e.g., Varela, Thompson, and Rosch 1991; Metzinger 2003]).

7 This critique has extended to epistemological accounts as well. For example, Lorraine Code asserts that the standardized epistemic subject, namely, that the self of the liberal tradition, "still exists is questionbegging in its assumption that he has in fact ever been more than a fictive creature" (Code 2006, 203). She provocatively claims that such a knower would have had to exist in only narrowly conceived theoretical places, "abstracted and isolated from the exigencies and vagaries of human lives" (ibid.). By placing the self in real-life terms as a knowing agent radically enveloped in the environment in which she lives, Code would take full account of circumstances and context, or in other words, the ecology of living. So instead of the view from nowhere, this trenchant critique (she calls an "ecological epistemology") ironically observes that the autonomous knower has a truncated view of the world and the bias of an insularity that limits his epistemological project: "Rooted in his observation post, which is strictly separated from anything he claims to know, this epistemic subject is restricted in his knowings to what he can [only] see from there" (ibid., 209). But more, "disconnected from accidents of embodiment, history, and place" that would discredit his knowledge claims, such a posture also expunges imagination, along with negotiation and interpretation, from his cognitive endeavors. To admit such subjective elements would otherwise compromise his neutral objectivity (ibid. 208), but in assuming such a stance the resulting omission of imagination is to reduce scientific thinking to an unrealizable mechanics. On this view, the liberal-conceived self is re-configured within an ecological ethos that acknowledges the value-laden character of knowledge and the subjectivity upon which it is based. 
1995) and cognitive science (e.g., Shapiro 2011). Basically, Cartesian conceptions of individual autonomy are being challenged by descriptions based upon the emergent and transient character of personal identity. Barely submerged beneath this alternate vision reside vague notions of organismic 'contingency' and 'self-actualization,' terms that tap into a postmodern vocabulary but are not generally regarded as suitable scientific language (Tauber 1995). Nevertheless, modeling complex systems characterized by dynamical processes ruled by probabilistic events requires new ways of describing biological phenomena (Tauber 2015b). ${ }^{8}$ We need not delve into this complex area to appreciate that once Enlightenment epistemological models are discarded (and the deconstruction of the self/nonself distinction in immune theory becomes important support for that move), substituting postmodern notions of agency are seamlessly invoked. Indeed, the intellectual Western elite has largely embraced a postmodern dismissal of essentialisms that have converged on the self, whether in art, philosophy, social sciences, or psychology, where agency is being reconfigured in unsettled ways.

To illustrate the close parallels between postmodern notions of agency and the immunological counterpart, let us take an example from the visual arts. Arguably, postmodernism began when abstract painting introduced 'de-representation' as a substitute for the natural mimicry that had dominated artistic orthodoxy for centuries. During the early $20^{\text {th }}$ century, the artistic avant garde rejected any formal criteria for 'realistic' depictions of reality. With the monumental Cubist works of 1907-1912, some have argued that Pablo Picasso and Georges Braque produced the greatest shift in art since the Renaissance (Golding 1988, xiii; Dickerman 2013; for overview see Rubin 1989; Braun and Rabinow 2014).9 That assessment is more than proclaiming a revolution in art, for the metaphysical foundations of Cubism go "all-the-way-down." Their visual invention depicts the world as fully integrated, obliterating heretofore generally accepted lines of demarcation. Human figures lose their individuality and merge into the background; their features, like the musical instruments or fruit of the still life pictures, have lost their representational status. The portraits deconstruct individual attributes and depict the subjects immersed in the world in idiosyncratic ways. The viewer then must deliberately reconstruct their identity. And, of course, that interpretation remains private and peculiar to the spectator, who is locked into her own understanding and intuitions.

The Cubists jolted the viewer with a radical vision. One must work hard at seeing, which in turn awakens a self-consciousness of how we perceive the world (Schjeldahl 2014). In these works, the artist has declared a revisionary epistemology: The world is, in

8 Such approaches clearly differ from a biology built from simple, self-contained entities and requires organizational principles perhaps best described by non-linear logic, complexity theory, and self-organizational precepts of various kinds. Immunology may well apply for these new ways of understanding the dynamics and organization of its object of study. After all, these theoretical approaches also seductively beckon in the neurosciences, genetics, metabolism, and ecology, where an emphasis on holism, chance, emergence and, most important, process, are increasingly perceived as characterizing biological systems (Kupiec 2009).

9 To what extent Braque contributed to the elaboration of Cubism is disputed, where some commentators see little contribution (e.g., Staller 2001; Dickerman 2013) others see Braque as an authentic co-inventor (e.g. Golding 1988) if not the originator (Butler 1994, 56-62); for diverse views see Zelevansky (1992). 
fact, of one piece, and to whatever extent one sees discrete objects or persons, a particular schema imposes those characteristics. And more, the products of those schema (reminiscent of Kantian phenomena) is not real in an ordinary sense, but rather possess particular characteristics derived from the viewer's culture and experience, for whatever ends and to whatever utility (Nisbett 2003). According to this view, the abstraction distills accidental details to reveal truths that lay beneath the surface (Poggi 1992, 129). In other words, Cubists refracted reality based not on ordinary vision (the purveyor of presumed falsehoods and distortions), but rather on a putative deeper conception of reality. ${ }^{10}$ Their pictorial manifesto asserted that abstractions reveal the epistemological bedrock of contrived human perceptions.

Three general conclusions emerge from Cubism: 1) different perspectives yield different realities (already propounded by Nietzsche a generation earlier); 2) the world has no 'natural kinds,' i.e., humans see discrete objects and their relationships in different ways and while there is a high degree of accordance, relativism has displaced the uniformity of some singular reality (Nisbett 2003); and 3) the subject is also integrated into her world so that bordered definitions of identity are replaced with contextual schemes. This epistemology closely resonates with key features underlying the ecological turn in immunology.

When immunity is understood as negotiating the organism's intercourse with the world, the boundaries of demarcation must allow for free exchange, and the immune system then becomes the mediator of that economy. On this view, the immune system joins the nervous system as an information processor, and the notion of immunity serving primarily as a defensive apparatus is subordinated to the larger task of placing the organism in its environment. In other words, the cognitive functions are primary, and the defensive mechanisms are secondary to the perceptive event (Tauber 2013a). Moreover, the perception of friend and foe is not determined by pre-determined meanings, but rather by the context of the object's presentation. ${ }^{11}$ And here a cascade of characteristics of immunity follow: 1 ) the

10 Such a presentation strips vision of the accidental to substitute the true 'essential' (Hughes 2013, 745). The Cubist seems to say, "I can take a wrench to reality" and present the angled planes of the object world, those facets and "edges on which Nature must turn; see me...open it up, seize it by a firm and encompassing grip" (Bell 2014, 23). 'Analytical cubism' has strong philosophical resonance with antirepresentational epistemologies, where the painter has rendered representations of things as no longer "mimetic labels for reality than are the words which donate them. Everything here is part of an artificial language... which aims at defamiliarizing, estranging relationship to reality... It reveals the (relativist) conventions by which it was made, which clearly vary from picture to picture... As we interrogate these pictures for mimetic clues... we find that they refuse to come together to make a single object or sitter... The parts literally do not have to work together, and so demand a different kind of critical justification" (Butler 1994, 67-8).

${ }^{11}$ How immune perception is understood varies with the underlying conception of the subject: In the modernist formulation, objects are represented to the self, and in the enactivist orientation, representation is replaced with presentation (Shapiro 2011; Tauber 2013a). In this latter formulation, meaning no longer rests on representations carrying essential definition, but rather the world is presented and recognized directly (and thus circumventing the problem of how to traverse the subject-object divide). Accordingy, the context of the perceived object determines meaning, and when applied to the ecological (or relational) orientation to model immunity, the object (distinguished as friend or foe) depends on the context of the encounter. 
discrimination of self and other have no formal or essential properties, and thus demarcations of self and other are fluid; 2) as a result of intimate cooperation alignments, individuality assumes an ambiguous standing, further obscuring the identity of an immune self; and 3) as observers we impose the subject-object divide that distorts the biological reality of process-driven phenomena; obviously scientific categorizations facilitate investigations, but current efforts have failed to capture the full dynamics of the system at work. ${ }^{12}$

In conclusion, the 'problem' of immune selfhood points to a striking correspondence between current efforts to revise the character of immune identity and the contextualization of the self so dramatically visualized by Picasso and Braque a century before the current shift in conceptions of the organism. I maintain that this shared conception of the self reflects a rejection of the modernist insular design of personal identity and replacement with a 'postmodern' deconstruction. Drawing such parallels is hardly extreme. After all, if a radical reorientation about the human agent took hold in the Western imagination, can we expect that repercussions of that shift would not be felt in a science so committed to ideas of agency embedded in its own theory? In other words, would not interpretations of immunology draw from a postmodern Zeitgeist if such models were readily available and then effectively captured immune phenomena? Given the rich metaphorical use of personhood throughout immunology's history (Tauber 1994), a tentative affirmation seems reasonable. I conclude with more wide-ranging postulations.

\section{Immunology in its Zeitgeist}

Investigative inquiry and the interpretation of epistemic findings are subtly oriented along certain non-epistemic lines, what Helen Longino calls, "contextual empiricism" (Longino 1996). The effort to identify background assumptions investigators employ in the questions they ask, the hypotheses they present, and the data they select to support their interpretations enriches our understanding of both scientific creativity and bias (i.e., emotional prejudice or unrecognized values [Howes 2012]). The case of the immune self suggests how this negotiation has occurred in a vibrant and rapidly evolving science. Perhaps because the changes have occurred so rapidly and because the human resonances be-

12 "Systems biology" has been vigorously promoted as the antidote to "molecular biology's obsession with metaphysical reductionism" (Woese 2004, 179; Kitano 2001). The basic goal, stimulated by the inability to process the myriad, complex data derived from modern molecular techniques coupled to the frustration to adequately model the organization and regulation of complex systems, is to reverse the prevalent reductive strategies that have failed to capture the dynamics of systems-as-systems. Simply, reductive strategies alone are inadequate to address the challenge of dynamic system modeling. Note, a systems approach may be applied to either the self/nonself or ecological conception of immunity. The distinguishing difference between these two orientations is, at minimum, how to conceive both the borders of the system (i.e., bounded limits of the regression analysis would be drawn differently) and the thresholds of immune activity counted as significant (i.e., the noise of the system assumes different weight in the two conceptions). So conceptually, the arguments for and against these competing views are not decided by the applicability of a system analysis, but rather on how the parameters of that analysis are chosen. Whether better results for modeling immune functions are obtained with an insular or ecological orientation will only be decided by future research. 
tween the laboratory and personal identity are so apparent, the case example of immunology's associations with its larger culture is of particular interest.

Strategies for reconciling internal and external accounts vary, for ideological influences invariably remain subtle; the commitments to obscure conceptual structures usually rest dormant; social, linguistic, and political effects often lay hidden, but in the end, each of these extracurricular influences plays some greater or lesser role, and the struggle for parsing the contribution of any 'outside' factor is an interpretive venture (Tauber 2009, 101ff.). In this regard, 'the self serves as a scaffold upon which to hang experimental data and an implicit presence to direct immunity's modeling. How the self is devised carries certain conceptual commitments ordering those interpretations. This process rests on the cognitive metaphor and linked notions about agency, whose long cultural pedigree and current social thinking carries meanings derived from a complex cultural construction. One might contest the extent of wider cultural correspondences, but the analogies are, at the very least, highly suggestive. This is not to contend that immune theory supports particular formulations of personal identity, only that echoes reverberate between certain hypotheses regarding immune models and the language - with its cultural meanings attached - used to describe those theories.

And if we cast the conceptual net towards a wider horizon, other more diffuse 'external' influences may be surmised as playing a role in the reception of immunology's ecological perspective. I am referring to the collective experience that the earth is facing an environmental crisis, if not a catastrophe. As a result, the ether of environmentalism has enveloped all of us, and immunology is finding its own expression in response. The environmental movement has heightened awareness of human dependence on intricate ecological balance, so, as opposed to only a generation ago, the immune system is now being firmly placed in an environmental context in which immunology and ecology have formed a new disciplinary amalgam. That professional response has roots in the political and social attempts to better situate human life in our natural habitats.

Similarly, the mind-set of globalization that would make an ecological sensibility a powerful determinant on scientific thinking is even further submerged beneath the laboratory. Nevertheless, how can we now think of agency absent consideration of the current vast economic globalization that accentuates open exchange and information transfer? This socio-economic transformation is a different way of presenting the human global socio-eco-political ecology, one that is based on cultural determinants, not the environment per se. Nevertheless, the same basic turn from insularity brings a set of social values, both benign and malignant: The call for tolerance and pluralism in identity politics, which, on the one hand supports ideals of inclusiveness, and on the other hand, highlights the traumas of social-religious xenophobia, which recalibrates personal identity on a very different basis. And adjoining that confrontation, universal moral claims and underlying conceptions of moral agency have been severely compromised, if not nullified. In short, the moral, social, and political definitions of agency are hotly contested.

The larger conceptual scaffolding upon which immune theory has been sketched represents another 'ecology' of immunology, namely, the ill-declared social context of the science writ-large. And here we join the seemingly endless debate about the construction of knowledge (Tauber 2009). On this multifocal account, drawn with sources from both within and outside the laboratory, immunology exhibits the easy transfer of cultural ideology into the science and then back again. How the boundary between the two domains is drawn, has 
been, and will continue to be, highly debated. Understanding why is part of the endeavor, indeed, such an analysis is a constitutive element of science conceived in its broadest social and intellectual context.

In this regard, immunology offers a particularly interesting framework for discussions of personhood. The evolution of the 'self concept tracks a conceptual arc that begins in the $17^{\text {th }}$ century with political philosophy centered on protecting citizen autonomy (denoting political and forensic rights), and culminates in postmodern critiques, where self has become a 'four-letter' word connoting the conceits of a male-configured construction of identity framed around power relations and dominance. That trajectory finds a corresponding history in immune theory that stretches on a spectrum from an assaulted insular self to an ecological understanding of an organism establishing its identity in concert with an environment of others. With this latest turn, individuality has been subordinated to relationships. This shift parallels the same transition undergone in the discourse on personal identity in the larger culture, and thus commentators have easily moved from one domain to the other. Indeed, here we have a vivid example of science and society in dialogue, where the boundaries separating these realms are open and easily traversed (Gieryn 1995).

The more general issue of science supporting agency with particular characteristics calls our attention, for the epistemological status of selfhood has central interest in how personal identity is configured far more broadly. If agency of a particular orientation can be shown to have scientific validity, then conceptions of collectives that develop from those initial characterizations assume credibility as expressions of some 'natural' order. For instance, if autonomy becomes a governing principle, the social standing of individuals within the collective leads to values prioritizing individuality in social organizations. In other words, naturalizing personal identity increasingly sways arguments about persons in virtually all of the contemporary debates about human nature, e.g., the evolutionary origins of altruism; the status of gender and sexuality as natural categories; the basis of violence; the morality of capitalism; the character of ethics. For those seeking consilience and a reduction of complex behaviors to genes and molecular transmitters, the immune self offers a ready platform for their scientism to support certain ideological positions over others. Yet, contemporary immunology has demonstrated that such characterizations are contested and preliminary at best. And more to the point, recognizing metaphoric elements in the scientific construct of selfhood must be acknowledged, which is not to dismiss the utility of such usage, but rather to recognize its rich idiomatic function.

This is not a trivial matter. The implications of the greater contest between modernist and postmodernist conceptions of the subject reflect a moral deliberation beyond the epistemological debate. On the account offered here, just as the immune self rests between two competing formulations - autonomous versus relational- so too are Western societies similarly balancing different conceptions of the citizen, in terms of individual and communal identities. And in that consideration, to deconstruct the self, immune or otherwise, is a transformation that has been strongly resisted. Indeed, the lines separating postmodernists and modernists remain firmly in place. The freedom associated with liberal precepts of individuality is not readily mortgaged, much less, forsaken. Indeed, despite efforts of the most influential twentieth-century philosophers to revamp the modernist conception of mind and personal identity that accompanies those descriptions, the basic appeal of human autonomy dominant during the modern period is not easily dislodged (Tauber 2013b). So the collective attraction of adhering to 'the self in its individualistic incarnation stays in service 
to a larger cultural agenda, namely, by fortifying a vision of personal identity conceived in terms of a judicial-political model of an agent's independence. This specific understanding of principled personhood carries a rich history and a strong political philosophy to bolster its credentials. Consequently, personal autonomy enjoys an entrenched position in contemporary thought. Its rejection moves against a strong cultural tide. ${ }^{13}$

In conclusion, the controversy swirling around the immune self mirrors a much larger drama, for just as traditional notions of immune identity have resisted displacement, so too have modernist notions of individuality remained anchored in the Western psyche. At the very least, by peering at both the laboratory and its encompassing intellectual framework we achieve insight that is enriched by both perspectives. Such is the dialogue between science and society, a conversation in which immunology has become a full partner.

\section{REFERENCES}

Anderson, W. and I.R. Mackay. 2014. Intolerant Bodies. A Short History of Autoimmunity. Baltimore: Johns Hopkins Press.

Bell, J. 2014. Taking a Wrench to Reality. The New York Review of Books 61: 23-5 (December 4, 2014).

Birch, C. and J.B. Cobb. 1981. The Liberation of Life. From the Cell to the Community. Cambridge: Cambridge University Press.

Boroditsky, L. 2009. How does Language Shape the Way We Think? In What's Next? Dispatches on the Future of Science, edited by M. Brockman, 116-29. New York: Vintage Press.

Braun, E. and R. Rabinow. 2014. Cubism. The Leonard A. Lauder Collection. New York: Metropolitan Museum of Art.

Brodin, P., V. Vojic, T. Gao, S. Bhattacharya, et. al. 2015. Variation in the Human Immune System is Largely Driven by Non-heritable Influences. Cell 160: 37-47. DOI: http://dx.doi.org/10.1016/j. cell.2014.12.020

Bucchi, M. and F. Neresini. 2008. Science and Public Participation. In The Handbook of Science and Technology Studies, $3^{\text {rd }}$ ed. Edited by E. J. Hackett, O. Amsterdamska, M. Lynch, and J. Wajcman, 449-72. Cambridge: MIT Press.

Buss, D. L. 2003. The Evolution of Desire. Strategies of Human Mating, $4^{\text {th }}$ ed. New York: Basic Books.

Butler, C. 1994. Early Modernism. Literature, Music and Painting in Europe 1900-1916. Oxford: Oxford University Press.

Butler, J. 1993. Bodies that Matter: On the Discursive Limits of 'Sex.' London: Routledge.

Cadava, E., P. Connor, and J-L. Nancy (eds.). 1991. Who Comes after the Subject? New York: Routledge.

Code, L. 2006. Ecological Thinking. The Politics of Epistemic Location. Oxford: Oxford University Press.

Crist, E. and A.I. Tauber. 1999. Selfhood, Immunity, and the Biological Imagination: The Thought of Frank Macfarlane Burnet. Biology and Philosophy. 15:509-33.

Croissant, J.L. and L. Smith-Doerr. 2008. Organizational Contexts of Science: Boundaries and Relationships between University and Industry. In The Handbook of Science and Technology Studies, $3^{\text {rd }}$ ed., edited by E.J. Hackett, O. Amsterdamska, M. Lynch, and J. Wajcman, 691-718. Cambridge: MIT Press.

Deleuze, G. and F. Guattari. 1977. Anti-Oedipus. Capitalism and Schizophrenia, vol. 1, translated by R. Hurley, M. Seem, and H. R. Lane. New York: Penguin.

Demas, G.E. and R. J. Nelson (eds.). 2011. Ecoimmunology. Oxford: Oxford University Press.

${ }^{13}$ How one is situated in this discussion depends on deep-set values and worldviews, which are seldom explored and much less confessed. I have set forth my orientation and how it has framed by own scholarly work elsewhere (Tauber 2006; 2014). 
Derrida, J. 1994. Specters of Marx: The State of the Debt, the Work of Mourning and the New International, translated by P. Kamuf. New York: Routledge.

-. 2003. Autoimmunity: Real and Symbolic Suicides. In Philosophy in a Time of Terror: Dialogues with Jürgen Habermas and Jacques Derrida, translated by P-A. Brault and M. Naas, edited by G. Borradori, 85136. Chicago: University of Chicago Press.

Dickerman, L. 2013. Inventing Abstraction, 1910-1925. How a Radical Idea Changed Modern Art. New York: The Museum of Modern Art.

Drengson, A. and Y. Inoue (eds.). 1995. The Deep Ecology Movement: An Introductory Anthology. Berkeley, CA: North Atlantic Books.

Esposito, R. 2011. Immunitas. The Protection and Negation of Life, translated by Z. Hanafi. London: Polity.

Foucault, M. 2005. The Hermeneutics of the Subject. Lectures at the College de France, 1981-1982, translated by G. Burchell. New York: Picador.

Gewin, V. 2011. An Outbreak of Eco-immunology Research. Frontiers in Ecology and Environment 9: 144.

Gieryn, T. F. 1995. Boundaries of Science. In Handbook of Science and Technology Studies, edited by S. Jasanoff, G. E. Markle, J. C. Petersen, and T. Pinch, 393-443. Thousand Oaks, CA: Sage Publications.

Gilbert, S.F., J. Sapp, A.I. Tauber. 2012. A Symbiotic View of Life: We have Never been Individuals. Quarterly Review of Biology 87: 325-41.

Golding, J. 1988. Cubism, A History and an Analysis 1907-1914, $3^{\text {rd }}$ ed., Cambridge: Harvard University Press.

Greenberg, D. S. 2007. Science for Sale: The Perils, Rewards, and Delusions of Campus Capitalism. Chicago: University of Chicago Press.

Grignolio, A., M. Mishto, A.M. Caetano Faria, P. Garagnani, C. Franceschi, and P. Tieri. 2014. Towards a Liquid Self: How Time, Geography, and Life Experiences Reshape the Biological Identity. Frontiers in Immunology 5: 153.

Gumperz, J.J. and C.J. Levinson. 1996. Rethinking Linguistic Relativity, Cambridge: Cambridge University Press.

Haraway D. J. 1989a. The Biopolitics of Postmodern Bodies: Determinations of Self in Immune System Discourse. Differences, 1: 3-43.

- 1989b. Primate Visions: Gender Race, and Nature in the World. London: Routledge, Kegan Paul.

—.1997.Modest_Witness@Second_Millenium.Female_Man $\bigodot_{-}$Meets_OncoMouse ${ }^{T M}$ :Feminism and Technoscience. New York: Routledge.

Harding, S. 1986. The Science Question in Feminism, New York: Cornell University Press.

-. 1991. Whose Science? Whose Knowledge? Thinking from Women's Lives. Ithaca: Cornell University Press. Hatzimoysis, A. (ed.) 2011. Self-knowledge. Oxford: Oxford University Press.

Hess, D., S. Breyman, N. Campbell, and B. Martin. 2008. Science, Technology, and Social Movements. In The Handbook of Science and Technology Studies, $3^{\text {rd }}$ ed., edited by E. J. Hackett, O. Amsterdamska, M. Lynch, and J. Wajcman, 473-98. Cambridge: MIT Press.

Howes, M. 2008. Conceptualizing the Maternal-fetal Relationship in Reproductive Immunology. In Crafting Immunity: Working Histories of Clinical Immunology, edited by K. Kroker, P.M.H. Mazumdar and J.E. Keelan, 247-71. Aldershot: Ashgate.

-. 2010. Self and nonself. In A Companion to the Philosophy of Biology, edited by S. Sarkar and A. Plutynski, 271-86. Malden, MA: Blackwell.

-. 2012. Managing Salience: The Importance of Intellectual Virtue in Analyses of Biased Scientific Reasoning. Hypatia 27: 736-54.

Hughes, G. 2013. Abstraction chez Delaunay. In Inventing Abstraction 1910-1925. How a Radical Idea Changed Modern Art, edited by L. Dickerman, 74-81. New York: Museum of Modern Art.

Irigaray, L. 1985. Speculum of the Other Woman, translated by G. Gill. Ithaca, NY: Cornell University Press. Keating, P. and A. Cambrosio. 2003. Biomedical Platforms: Realigning the Normal and the Pathological in Late-Twentieth-Century Medicine. Cambridge: MIT Press. 
Keller, E. F. 1982. Feminism and Science. Signs: Journal of Women in Culture and Society 7:589-602.

-. 1983. A Feeling for the Organism, The Life and Work of Barbara McClintock. New York: Freeman.

-. 1985. Reflections on Gender and Science. New Haven: Yale University Press.

- 1992. Secrets of Life, Secrets of Death. Essays on Language, Gender, and Science, 15-36. New York: Routledge.

Kitano, H. 2001. Systems Biology: Toward System-level Understanding of Biological Systems. In Foundations of Systems Biology, edited by H. Kitano, 1-36. Cambridge: MIT Press.

Kupiec, J-J. 2009. The Origins of Individuals, translated by M. Hutchings and J. Hutchings, Singapore: World Scientific Publishing.

Lakoff, G. 1987. Women, Fire and Dangerous things: What Categories Reveal about the Mind. Chicago: University of Chicago Press.

Langacker, R.W. 2008. Cognitive Grammar. A Basic Introduction. Oxford: Oxford University Press.

Langman, R. (ed.). 2000. Self-Non-self Discrimination Revisited. Seminars in Immunology 12, Issue no. 3.

Latour B. 1987. Science in Action. How to Follow Scientists and Engineers through Society. Cambridge: Harvard University Press.

-. 1988. The Pasteurization of France. Cambridge: Harvard University Press.

- and S. Woolgar. 1979. Laboratory Life: The Construction of Scientific Facts. Princeton: Princeton University Press.

Levins, R. and R. L. Lewontin. 1985. The Dialectical Biologist. Cambridge: Harvard University Press.

Longino, H. 1996. Cognitive and Non-cognitive Values in Science. Rethinking the Dichotomy. In Feminism, Science and the Philosophy of Science, edited by L. H. Nelson and J. Nelson, 39-58. Dordrecht: Kluwer Academic Publishers.

Löwy, I. 1991. The Immunological Construction of the Self. In Organism and the Origins of Self, edited by A.I. Tauber, 43-75. Dordrecht: Kluwer Academic Publishers.

-. 1992. The Strength of Loose Concepts - Boundary Concepts, Federative Experimental Strategies and Disciplinary Growth: The Case of Immunology. History of Science 30: 371-96.

-. 1996. Between Bench and Bedside. Science, Healing, and Interleukin-2 in a Cancer Ward. Cambridge: Harvard University Press.

Maligoli, D. and E. Ottaviani (eds.). 2014. Eco-immunology. Evolutive Aspects and Future Perspectives. Dordrecht: Springer.

Margulis, L. 1991. Symbiogenesis and Symbionticism. In Symbiosis as a Source of Evolutionary Innovation, edited by L. Margulis and R. Fester, 1-14. Cambridge: MIT Press.

Martin, E. 1990. Toward an Anthropology of Immunology: The Body as Nation State. Medical Anthropology Quarterly 4: 410-26.

-. 1994. Flexible Bodies. The Role of Immunity in American Culture from the Days of Polio to the Age of AIDS. Boston: Beacon Press.

Martin, L.B., D.M. Hawley, and D. R. Ardia, 2011. An Introduction to Ecological Immunology. Functional Ecology 25: 1-4.

Matzinger, P. 1994. Tolerance, Danger, and the Extended Family. Annual Review of Immunology 12: 9911045.

Metzinger, T. 2003. Being No One. The Self-model Theory of Subjectivity. Cambridge: MIT Press.

Mody, C.C.M. and D. Kaiser. 2008. Scientific Training and the Creation of Scientific Knowledge. In The Handbook of Science and Technology Studies, $3^{\text {rd }}$ ed., edited by E. J. Hackett, O. Amsterdamska, M. Lynch, and J. Wajcman, 377-402. Cambridge: MIT Press.

Morris, B. 1994. Anthropology of the Self. The Individual in Cultural Perspective. London: Pluto Press.

Moulin, A-M. 2001. Multiple Splendor: The One and any Versions of the Immune System. In Singular Selves: Historical Issues and Contemporary Debates in Immunology, edited by A-M Moulin and A. Cambrosio, 228-243. Amsterdam: Elsevier.

- and A. Cambrosio. (eds.). 2001. Singular Selves: Historical Issues and Contemporary Debates in Immunology. Amsterdam: Elsevier. 
Napier, D. 2003. The Age of Immunology. Conceiving a Future in an Alienating World. Chicago: University of Chicago Press.

-. 2012a. Introduction. Cultural Anthropology 27:118-21.

-. 2012b. Nonself Help: How Immunology Might Reframe the Enlightenment. Cultural Anthropology 27:122-37.

Nisbett, R. E. 2003. The Geography of Thought. How Asians and Westerners Think Differently. New York: Free Press.

Poggi, C. 1992. Braque's Early Papiers Collés: The Certainties of Faux Bois. In Picasso and Braque: A Symposium, edited by L. Zelevansky, 129-149. New York: Museum of Modern Art.

Pradeu, T. 2010. What is an Organism? An Immunological Answer. History and Philosophy of the Life Sciences 32: 247-268.

-. 2012. The Limits of the Self: Immunology and Biological Identity. New York: Oxford University Press.

-. 2013. Immunity and the Emergence of Individuality. In From Groups to Individuals. Evolution and Emerging Individuality, edited by F. Bouchard and P. Huneman, 77-96. Cambridge: MIT Press.

Rappert, B., B. Balmer, and J. Stone. 2008. Science, Technology, and the Military: Priorities, Preoccupations, and Possibilities. In The Handbook of Science and Technology Studies, $3^{\text {rd }}$ ed., edited by E. J. Hackett, O. Amsterdamska, M. Lynch, and J. Wajcman, 619-39. Cambridge: MIT Press.

Ridley, M. 1998. The Origins of Virtue. Human Instincts and the Evolution of Cooperation. New York: Penguin.

Rossiianov, K. 2008. Taming the Primitive: Elie Metchnikoff and His Discovery of Immune Cells. Osiris 23: 213-29.

Rouse, J. 1987. Knowledge and Power. Toward a Political Philosophy of Science. Ithaca: Cornell University Press.

Rubin, W. 1989. Picasso and Braque. Pioneering Cubism. New York: Museum of Modern Art.

Scheper-Hughes, N. 2012. The Other Who is Also Oneself: Immunological Risk, Danger and Recognition. Cultural Anthropology, 27: 162-7.

Silverstein, A.M. 2009. A History of Immunology, 2nd ed. Amsterdam: Elsevier.

Sloterdijk, P. 2011. Bubbles: Spheres I. Los Angeles: Semiotext(e).

Schjeldahl, P. 2014. In with the New. The New Yorker 90: 78-9 (October 27, 2014).

Shapiro L. 2011. Embodied Cognition. New York: Routledge.

Staller, N. 2001. A Sum of Deconstructions: Picasso's Cultures and the Creation of Cubism. New Haven: Yale University Press.

Stollar, P. 2012. Immunology and the Between. Cultural Anthropology 27:175-80.

Swiatczak, B. 2013. Immune Balance: The Development of the Idea and its Applications. Journal of the History of Biology 2014. 14: 411-442. DOI 10.1007/s10739-013-9370-z

Tauber, A.I. 1994. The Immune Self. Theory or Metaphor? Cambridge: Cambridge University Press.

-. 1995. Postmodernism and Immune Selfhood. Science in Context 8: 579-607.

-. 1997. Historical and Philosophical Perspectives on Immune Cognition. Journal of the History of Biology 30: 419-440.

-. 1999. The Elusive Immune Self: A Case of Category Errors. Perspectives in Biology and Medicine 42: 45974.

-. 2000. Moving beyond the Immune Self? Seminars in Immunology 12: 241-48.

-. 2006. Scholarship as Self-knowledge: A Case Study. In The Historiography of Contemporary Science, Technology, and Medicine. Writing Recent Science, edited by R. E. Doel and T. Soderqvist, 128-149. New York: Routledge.

-. 2008a. Expanding Immunology: Defensive versus Ecological Perspectives. Essay Review: Defending Life. The Nature of Host-parasite Relations by Elling Ulvestad, Dordrecht: Springer, 2007. Perspectives in Biology and Medicine 51:270-84.

-. 2008b. The Immune System and its Ecology. Philosophy of Science 75:224-45.

-. 2009. Science and the Quest for Meaning. Waco, TX: Baylor University Press. 
-. 2010. Freud, the Reluctant Philosopher. Princeton: Princeton University Press.

-. 2013a. Immunology's Theories of Cognition. History and Philosophy of the Life Sciences 35: 239-64.

-. 2013b. Requiem for the Ego. Freud and the Origins of Postmodernism. Stanford: Stanford University Press.

-. 2014. Philosophy as Self-knowledge. Philosophia 42:1-23, 2014 DOI 10.1007/s11406-013-9474-x. http://link.springer.com/article/10.1007\%2Fs11406-013-9474x/fulltext.html

-. 2015a. Reconceiving Autoimmunity: An Overview. Journal of Theoretical Biology, 375: 52-60.

-. 2015b. The Biological Notion of Self and Nonself. Stanford Encyclopedia of Science http://plato.stanford. edu/entries/biology-self/2015

Taylor, C. 1989. Sources of the Self. Cambridge: Harvard University Press.

Taylor, M.C. 1993. The Betrayal of the Body: Live Not. In Nots, 214-55. Chicago: University of Chicago Press.

Ulvestad, E. 2007. Defending Life. The Nature of Host-Parasite Relations. Dordrecht: Springer.

Varela F., E.T. Thompson and E. Rosch. 1991. The Embodied Mind: Cognitive Science and Human Experience. Cambridge: The MIT Press.

Wade, N. 2014. A Troublesome Inheritance. Genes, Race and Human History. New York: Penguin.

Weasel, L. 2001. Dismantling the Self/other Dichotomy in Science: Towards a Feminist Model of the Immune System. Hypatia 16: 27-44.

Wilson, R. 2005. Genes and the Agents of Life: The Individual in the Fragile Sciences. New York: Cambridge University Press.

Woese, C. R. 2004. A New Biology for a New Century. Microbiology and Molecular Biology Reviews 68:17386.

Wright, R. 1995. The Moral Animal. Why we are the Way we are: The Science of Evolutionary Psychology. New York: Vintage.

Zelevansky, L. 1992. Picasso and Braque, A Symposium. New York: Museum of Modern Art.

Alfred I. Tauber, Professor of Philosophy, emeritus and Zoltan Kohn Professor of Medicine, emeritus at Boston University, was Director of the Center for Philosophy and History of Science, 1993-2010. He has published extensively in ethics and science studies with an emphasis on the critical examination of immunology's theory and historical development.

Address: 22 Hardy Lane, Boscawen, NH 03303, USA. Email: ait@bu.edu 